\title{
The Microstructure OF THE TIPS MARKET
}

- The potential advantages of Treasury inflationprotected securities have yet to be fully realized, mainly because TIPS are not as liquid as nominal Treasury securities.

- The less liquid nature of TIPS may adversely affect prices relative to those of nominal securities, offsetting the benefits of TIPS having no inflation risk.

- A study of TIPS, using novel tick data from the interdealer market, provides new evidence on the liquidity of the securities and how liquidity differs from that of nominal securities.

- Analysis of various liquidity measures suggests that trading activity and the incidence of posted quotes may be better cross-sectional gauges of TIPS liquidity than bid-ask spreads or quoted depth.

- Differences in intraday trading patterns and announcement effects between TIPS and nominal securities likely reflect the different use, ownership, and cash-flow attributes of the securities.

\section{INTRODUCTION}

The introduction of Treasury inflation-protected securities (TIPS) in the United States in 1997 offered multiple potential benefits. First, the development was intended to offer investors a security that would enable them to hedge inflation. Second, by taking on the risk of inflation, the U.S. Treasury Department would not have to pay an inflation risk premium on its securities, thereby lowering its expected borrowing costs. ${ }^{1}$ And third, the securities would provide a market-based measure of inflation expectations. It would be possible to gauge market expectations of inflation by comparing the yields on nominal Treasury securities with yields on inflation-protected securities of comparable maturities.

These potential benefits have not been fully realized, mainly because TIPS lack market liquidity compared with nominal securities. $^{2}$ This lack of liquidity is thought to result in TIPS yields having a liquidity premium relative to nominal securities, which offsets the inflation risk premium. ${ }^{3}$ Similarly, the presence of a liquidity premium in TIPS yields complicates inferences of inflation expectations, particularly if the

${ }^{1}$ Campbell and Shiller (1997) estimate the inflation risk premium for a fiveyear nominal bond to be between 50 and 100 basis points. Buraschi and Jiltsov (2005) estimate the ten-year inflation risk premium to average 70 basis points. ${ }^{2}$ Market liquidity is defined here as the cost of executing a trade, which can depend on the trade's size, timing, venue, and counterparties. It is often gauged by various measures, including the bid-ask spread, the price impact of trades, quoted depth, and trading activity.
Michael J. Fleming is a vice president at the Federal Reserve Bank of New York; Neel Krishnan is a former research associate at the Bank.

Correspondence: michael.fleming@ny.frb.org
The authors thank Michelle Steinberg Ezer, Joshua Frost, Kenneth Garbade, Adam Reed, two anonymous referees, and participants at the Federal Reserve Bank of New York Conference on Inflation-Indexed Securities and Inflation Risk Management for helpful comments and Nicholas Klagge for excellent research assistance. The views expressed are those of the authors and do not necessarily reflect the position of the Federal Reserve Bank of New York or the Federal Reserve System. 
premium changes over time. However, despite the importance of TIPS liquidity and the market's large size ( $\$ 728$ billion as of November 30, 2011), there has been virtually no quantitative evidence on the securities' liquidity.

The Federal Reserve publishes data on trading volume in Treasury securities that show that trading activity in TIPS is much lower than activity in nominal securities. ${ }^{4}$ However, the Fed data are aggregated over the week and across all TIPS

In this article, we use novel tick data from the interdealer market to characterize the liquidity of the market for TIPS.

and provide information only on trading volume. So these data are unable to provide information about activity in particular TIPS, activity over the day or week, or other measures of TIPS liquidity, such as bid-ask spreads.

In this article, we use novel tick data from the interdealer market to characterize the liquidity of the market for TIPS. We examine how trading activity breaks down across sectors, over securities' life cycles, and during the trading day. We also characterize liquidity using a variety of measures, including the bid-ask spread, the price impact of trades, quoted depth, and the incidence of two-sided quotes (that is, both a posted bid price and a posted offer price). Lastly, we analyze how major announcements affect TIPS activity and how the market adjusts to these announcements.

Our study relates most closely to the literature examining the microstructure of the nominal Treasury securities market, particularly studies that characterize the liquidity of the market (Fleming 1997), liquidity over securities' life cycles (Fleming 2002; Goldreich, Hanke, and Nath 2005; Barclay, Hendershott, and Kotz 2006), and the announcement adjustment process (Fleming and Remolona 1999; Balduzzi, Elton, and Green 2001; Fleming and Piazzesi 2005). Our work also relates to studies of announcement effects in the indexed markets, especially that of Beechey and Wright (2009), which also analyzes intraday data but is different in its focus on liquidity and the announcement adjustment process as opposed to price-level effects.

\footnotetext{
${ }^{3}$ D'Amico, Kim, and Wei (2008) estimate that the liquidity premium was about 1 percent in the early years of the TIPS program. Pflueger and Viceira (2011) find that the liquidity premium is around 40 to 70 basis points during normal times, but was more during the early years of TIPS and during the 2008-09 financial crisis. Sack and Elsasser (2004) argue that TIPS have not reduced the Treasury's financing costs because of several factors, including lower liquidity. Roush (2008) finds that TIPS have saved the government money, except during the early years of the program. Dudley, Roush, and Ezer (2009) show that the ex ante costs of TIPS issuance are about equal to the costs of nominal securities issuance.

${ }^{4}$ The data are available at http://www.newyorkfed.org/markets/ primarydealers.html.
}

Examining the TIPS market, we find a marked difference in trading activity between on-the-run and off-the-run securities, as in the nominal market. ${ }^{5}$ There is little difference in bid-ask spreads or quoted depth between on-the-run and off-the-run securities in the TIPS market, in contrast to the nominal market, but we do find a sharp difference in the incidence of posted quotes. Our findings suggest that trading activity and the incidence of posted quotes may be better cross-sectional measures of TIPS liquidity than bid-ask spreads or quoted depth.

We also find several differences between TIPS and nominal securities in intraday patterns and announcement effects, a result that likely reflects the different use, ownership, and cash flow attributes of the securities. In particular, we find that intraday TIPS activity peaks later in the morning than does intraday nominal activity. Moreover, TIPS auctions and consumer price index (CPI) announcements spur significant increases in TIPS trading activity, whereas employment reports do not.

Our study proceeds as follows. Section 2 discusses institutional features of the market for TIPS. In Section 3, we describe the tick data used in our empirical analysis. Section 4 reports our empirical results, including trading activity by sector, the liquidity of on-the-run and off-the-run securities, price impact estimates, intraday patterns in trading activity and liquidity, and the effects of major announcements. Section 5 concludes.

\section{Market Structure}

TIPS were introduced by the U.S. Treasury Department in January 1997. The principal of these securities is adjusted for inflation over time according to the non-seasonally-adjusted consumer price index for all urban consumers. The Treasury makes semiannual interest payments, which are a fixed percentage of the inflation-adjusted principal. The greater of the inflation-adjusted principal and the original principal is paid at maturity.

The Treasury currently issues TIPS with original maturities of five, ten, and thirty years. New five-year notes are issued once a year in April and then reopened in August and December (a reopening refers to the additional issuance of an outstanding security). New ten-year notes are issued in January and July; the January notes are reopened in March and May and the July notes in September and November. New thirtyyear bonds are issued in February and reopened in June and October. Twenty-year bonds are not currently issued, but were between 2004 and 2009. ${ }^{6}$

\footnotetext{
${ }^{5}$ On-the-run securities are the most recently issued securities of a given maturity. Off-the-run securities are previously issued securities of a given maturity.

${ }^{6}$ In November 2009, the Treasury announced it was reintroducing the thirtyyear inflation-indexed bond, which had previously been issued between 1998 and 2001. At the same time, it discontinued issuance of twenty-year bonds.
} 
TIPS are sold in the primary market via single-price auctions, like nominal Treasury securities, and are disproportionately purchased at auction by domestic investment accounts. Analyzing Treasury Department data, Fleming (2007) finds that investment funds (which include mutual funds and hedge funds) account for 30.2 percent of TIPS sold at auction, but only 11.5 percent of nominal notes and bonds. In contrast, dealers and brokers account for 56.3 percent of TIPS sold at auction versus 63.6 percent of nominal notes and bonds, and foreign and international investors account for 8.2 percent of TIPS sold at auction and 21.1 percent of nominal notes and bonds. ${ }^{7}$

The secondary-market structure for TIPS is also similar to that for nominal Treasury securities. Trading takes place in a multiple-dealer over-the-counter market. The predominant market makers are the primary government securities

Much of the activity in TIPS occurs on an outright cash-for-security basis, as is typical in the nominal market. However, a large share of TIPS activity occurs via "breakeven inflation" trades, whereby a particular inflation-indexed security is traded against a proportionate quantity of a particular nominal security.

dealers-those dealers who have a trading relationship with the Federal Reserve. The primary dealers trade with the Fed, their customers, and one another. Nearly all interdealer trading occurs via interdealer brokers.

Interdealer brokers provide dealers and other financial firms with electronic screens posting the best bid and offer prices provided by the dealers (either electronically or by phone) along with the associated quantities. Quotes are binding until and unless withdrawn. Dealers execute trades by contacting the brokers (either electronically or by phone), who post the resulting trade price and size on their screens. The brokers thus match buyers and sellers while ensuring anonymity, even after a trade. In compensation for their services, the brokers charge a fee.

An interesting feature of interdealer trading is the brokers' expandable limit order protocol. As explained in Boni and Leach (2004), a Treasury market trader whose order has been executed has the right of refusal to trade additional volume

\footnotetext{
${ }^{7}$ Some of the investment accounts may have foreign investors as clients, so these data may understate the proportion of funds coming from foreign accounts.
}

at the same price. In addition to such "workups," electronic systems allow traders to enter "iceberg" orders, whereby they can choose to show only part of the amount they are willing to trade. There is an incentive to display quantity, however, or at least enter it as hidden, because shown quantity takes priority over hidden quantity, and hidden quantity at a given price is executed against before a workup starts. Fleming and Mizrach (2009) find that hidden depth accounts for only a small share of total depth in the nominal market.

Much of the activity in TIPS occurs on an outright cash-forsecurity basis, as is typical in the nominal market. However, a large share of TIPS activity occurs via "breakeven inflation" trades, whereby a particular inflation-indexed security is traded against a proportionate quantity of a particular nominal security. Some TIPS are also traded via issue-for-issue switch trades, whereby a particular inflation-indexed security is traded against a proportionate quantity of another inflation-indexed security. In contrast to the nominal market, there is no organized futures market in TIPS. ${ }^{8}$

Data on outstanding ownership of TIPS are less comprehensive and more dispersed than information on buyers of securities at auction. Positions data reported to the Federal Reserve Bank of New York by the primary dealers show that the dealers' aggregate holdings of TIPS averaged \$2.2 billion over the period March 2, 2005, to March 26, 2008 (a period closely corresponding to our sample period), and ranged from $-\$ 3.2$ billion to $\$ 8.1$ billion. In contrast, nominal Treasury note and bond holdings averaged $-\$ 125.6$ billion over this period and ranged from $-\$ 178.6$ billion to $-\$ 65.1$ billion. Examining Securities and Exchange Commission 13F filings of institutional investment managers, Fleckenstein, Longstaff, and Lustig (2010) find that, in their sample, investment firms hold 21 percent of TIPS, versus only 5 percent of maturitymatched nominal bonds.

\section{Data}

Our analysis is based on proprietary tick data covering a subset of outright TIPS trading in the interdealer market. The database provides a record of trades and quotes for every inflationindexed security outstanding. The trade data include price, quantity, and initiator (buyer or seller). The quote data include the best bid and offer prices and the total displayed quantities available at those prices (albeit not hidden quantities). Trades and quotes are time-stamped to the second.

${ }^{8}$ Futures on five- and ten-year TIPS were listed on the Chicago Board of Trade between July 1997 and March 1998, and futures on the thirty-year bond were listed between April 1998 and June 2000. 
Our sample period runs from March 4, 2005, to March 27, 2008. We retain 757 trading days in our analysis after excluding 32 holidays and 11 trading days for which data are missing for much of the day. ${ }^{9}$ We retain trading days when data are available for all securities except the on-the-run ten-year note (244 days), the just-off-the-run ten-year note (29 days), and/or the on-the-run twenty-year bond (224 days). When on-therun data are missing, we impute trading activity based on the securities' share of overall TIPS volume for days when data are not missing. ${ }^{10}$

Twenty-seven TIPS are outstanding over all or part of our sample period, comprising three five-year notes, seventeen ten-year notes, four twenty-year bonds, and three thirty-year bonds. Eleven of the twenty-seven TIPS were first issued during the sample period, comprising two five-year notes, six ten-year notes, and three twenty-year bonds. Two TIPS matured during the sample period, both ten-year notes.

Outright TIPS trading in our sample averages $\$ 563$ million per day. In contrast, total interdealer trading in TIPS over this same period, as reported by the primary dealers (and including significant double-counting), averages $\$ 2,612$ million per day. A comparison of these numbers suggests that the outright trading in our data set accounts for about 43 percent of interdealer TIPS trading. ${ }^{11}$ Breakeven inflation trading and issue-for-issue switch trading likely account for much of the difference. ${ }^{12}$

Meanwhile, primary dealers reported nominal interdealer trading over the same period of $\$ 232$ billion per day, on average. In other words, TIPS accounted for just over 1 percent

\footnotetext{
${ }^{9}$ In particular, we exclude days for which we are missing at least two consecutive hours of activity for all TIPS during New York trading hours (defined as 7:30 a.m. to 5 p.m. Eastern time). We also impose a filter to exclude data thought to be erroneous or unrepresentative by dropping prices that are less than $\$ 80$ or more than $\$ 160$ (per $\$ 100$ par) and bid-ask spreads that are less than zero or more than $\$ 1$ (per $\$ 100$ par).

${ }^{10}$ We do not impute trading activity on days for which we are missing just-offthe-run note data. Such an imputation would not substantively affect our results given the relative inactivity of the note and the few days of data that are missing.

${ }^{11}$ It is somewhat problematic to compare these numbers directly, because our outright volume may include some trading by nonprimary dealers and because the interdealer numbers reported to the Fed (on the "FR 2004 Report") include significant double-counting. That said, discussions with market participants suggest that virtually all interdealer broker trading of TIPS is in fact between primary dealers. Assuming that only primary dealers trade on interdealer platforms, then our data coverage share equals our outright volume divided by one-half of FR 2004 interdealer broker volume. An additional minor complication is that our data exclude when-issued trading in new securities that occurs between the time a security is announced for auction and the time the security becomes the on-the-run security (which occurs the day following auction).

${ }^{12}$ A comparison with the FR 2004 data also shows that our data cover a declining share of trading activity over time. Additional data from the interdealer market suggest that this decline is explained by a shift in activity from outright trading to breakeven inflation trading and issue-for-issue switch trading.
}

of Treasury trading in the interdealer market during our sample period. In contrast, TIPS accounted for about 7 percent of marketable Treasury debt at the beginning of our sample period and 10 percent at the end. ${ }^{13}$ The turnover ratio for TIPS is thus only about one-seventh to one-tenth the turnover ratio for nominal Treasury securities.

As noted, a feature of interdealer trading is the presence of workups and iceberg orders. Our data are processed in a manner that aggregates the outcome of each workup into a single trade (most microstructure studies of the nominal Treasury market process their data in the same manner). That is, any particular trade in our data set was conducted at a particular price, and at virtually the same time, but may have occurred in a sequence of steps, possibly with multiple counterparties. Based on this trade definition, we find an average daily number of sixty-seven trades over our sample and an average trade size of $\$ 8.7$ million. ${ }^{14}$

\section{Results}

\subsection{Trading Activity by Sector}

Trading activity in TIPS is concentrated in notes, more so than might be implied by issuance amounts alone. In terms of daily trading volume by sector, $\$ 403$ million (or 71.7 percent of all TIPS activity) occurs in ten-year notes, $\$ 110$ million (19.5 percent) in five-year notes, and $\$ 50$ million (8.9 percent) in twenty- and thirty-year bonds (Table 1). Bonds account for 25.9 percent of TIPS outstanding at the beginning of our sample period and 27.2 percent at the end. It follows that the turnover ratio for bonds is less than one-third that for notes. ${ }^{15}$ A similar pattern is observed in the nominal market, likely reflecting greater hedging and speculative trading demand for notes. ${ }^{16}$

\footnotetext{
${ }^{13}$ The percentages are calculated using the Treasury's Monthly Statement of the Public Debt from February 2005 and March 2008, available at http:// www.treasurydirect.gov/govt/reports/pd/mspd/mspd.htm.

${ }^{14}$ We calculate trade size, quote size, and bid-ask spread averages by first averaging on a daily basis and then averaging across days. It follows that our reported average trade size need not (and does not) equal average daily volume divided by the average number of trades.

${ }^{15}$ Assuming a 26.5 percent issuance share, 8.9 percent divided by 26.5 percent equals 0.335 , whereas (1-8.9 percent) divided by (1-26.5 percent) equals 1.239 , which is 3.7 times larger than 0.335 .

${ }^{16}$ Over the period March 2, 2005, to March 26, 2008, for example, dealers reported average daily trading volume of $\$ 125.4$ billion in nominal notes and bonds with times to maturities of more than six but not more than eleven years, and $\$ 29.5$ billion in nominal notes and bonds with times to maturities of more than eleven years.
} 
TABLE 1

Trading Activity by Sector

\begin{tabular}{lccc} 
Sector & $\begin{array}{c}\text { Volume } \\
\text { (Millions of } \\
\text { Dollars, } \\
\text { Par Value) }\end{array}$ & $\begin{array}{c}\text { Number of } \\
\text { Trades }\end{array}$ & $\begin{array}{c}\text { Trade Size } \\
\text { (Millions of } \\
\text { Dollars, } \\
\text { Par Value) }\end{array}$ \\
\hline Five-year & 109.6 & 10.8 & 9.6 \\
Ten-year & 403.2 & 45.0 & 9.4 \\
Twenty-year & 36.4 & 7.3 & 4.7 \\
Thirty-year & 13.4 & 4.2 & 3.3 \\
Total & 562.6 & 67.3 & 8.7
\end{tabular}

Source: Authors' calculations, based on proprietary data from the interdealer market.

Notes: The table reports average daily outright trading activity in TIPS over the March 4, 2005, to March 27, 2008, period. Sector buckets are defined according to securities' time to maturity at issuance.

TABLE 2

Trading Activity by Time to Maturity

\begin{tabular}{lccc} 
Time to Maturity & $\begin{array}{c}\text { Volume } \\
\text { (Millions of } \\
\text { Dollars, } \\
\text { Par Value) }\end{array}$ & $\begin{array}{c}\text { Number of } \\
\text { Trades }\end{array}$ & $\begin{array}{c}\text { Trade Size } \\
\text { (Millions of } \\
\text { Dollars, } \\
\text { Par Value) }\end{array}$ \\
\hline Zero to five years & 314.4 & 30.5 & 10.3 \\
Five to ten years & 198.4 & 25.3 & 7.7 \\
More than ten years & 49.8 & 11.4 & 4.3 \\
Total & 562.6 & 67.3 & 8.7
\end{tabular}

Source: Authors' calculations, based on proprietary data from the interdealer market.

Notes: The table reports average daily outright trading activity in TIPS over the March 4, 2005, to March 27, 2008, period. The zero-to-five-year bracket includes all trading in on-the-run five-year notes, which sometimes have slightly more than five years to maturity; the five-to-ten-year bracket includes all trading in on-the-run ten-year notes, which sometimes have slightly more than ten years to maturity.

An alternative breakdown of volume, by time to maturity, shows that most activity occurs in TIPS maturing within five years (Table 2). Interestingly, only half of the volume in TIPS originally issued as ten-year notes occurs when the securities have more than five years to maturity $(198.4 / 403.2=0.49)$. This finding suggests that some ten-year notes continue to be actively traded years after issuance.

The pattern for number of trades is similar to that for volume but less skewed toward notes, reflecting the latter's higher average trade size, which ranges from $\$ 9.6$ million for five-year notes to $\$ 3.3$ million for thirty-year bonds.
TABLE 3

Trading Activity by On-the-Run/Off-the-Run Status

Panel A: On-the-Run Securities

\begin{tabular}{lccc} 
Sector & $\begin{array}{c}\text { Volume } \\
\text { (Millions of } \\
\text { Dollars, } \\
\text { Par Value) }\end{array}$ & $\begin{array}{c}\text { Number of } \\
\text { Trades }\end{array}$ & $\begin{array}{c}\text { Trade Size } \\
\text { (Millions of } \\
\text { Dollars, } \\
\text { Par Value) }\end{array}$ \\
\hline Five-year & 86.6 & 8.8 & 9.3 \\
Ten-year & 136.8 & 17.5 & 7.2 \\
Twenty-year & 29.7 & 6.0 & 4.6
\end{tabular}

Panel B: Off-the-Run Securities

\begin{tabular}{lccc} 
Sector & $\begin{array}{c}\text { Volume } \\
\text { (Millions of } \\
\text { Dollars, } \\
\text { Par Value) }\end{array}$ & $\begin{array}{c}\text { Number of } \\
\text { Trades }\end{array}$ & $\begin{array}{c}\text { Trade Size } \\
\text { (Millions of } \\
\text { Dollars, } \\
\text { Par Value) }\end{array}$ \\
\hline Five-year & 27.2 & 2.4 & 10.8 \\
Ten-year & 22.0 & 2.3 & 9.9 \\
Twenty-year & 6.4 & 1.2 & 5.3
\end{tabular}

Source: Authors' calculations, based on proprietary data from the interdealer market.

Notes: The table reports average daily outright trading activity in on-the-run and off-the-run TIPS over the March 4, 2005, to March 27, 2008, period. Off-the-run averages are per security and are not aggregated across securities.

This pattern is also observed in the nominal market (see, for example, Fleming [2003] and Fleming and Mizrach [2009]) and probably reflects the higher duration and hence interest rate sensitivity of the longer-maturity instruments.

\subsection{Liquidity of On-the-Run and Off-the-Run Securities}

Trading activity for on-the-run TIPS is substantially higher than it is for off-the-run TIPS (Table 3). Daily trading in the on-the-run ten-year note averages $\$ 137$ million, more than six times the average trading volume ( $\$ 22$ million) of individual off-the-run ten-year notes. The comparable ratio for the fiveyear note is just over 3 ( $\$ 87$ million versus $\$ 27$ million), and it is somewhat less than 5 for the twenty-year bond ( $\$ 30$ million versus $\$ 6$ million). Such on-the-run/off-the-run differentials are just as striking in the nominal market (see Fleming [2002]; Fabozzi and Fleming [2005]; Goldreich, Hanke, and Nath [2005]; and Barclay, Hendershott, and Kotz [2006]), reflecting 
Chart 1A

Trading Volume around Off-the-Run Date

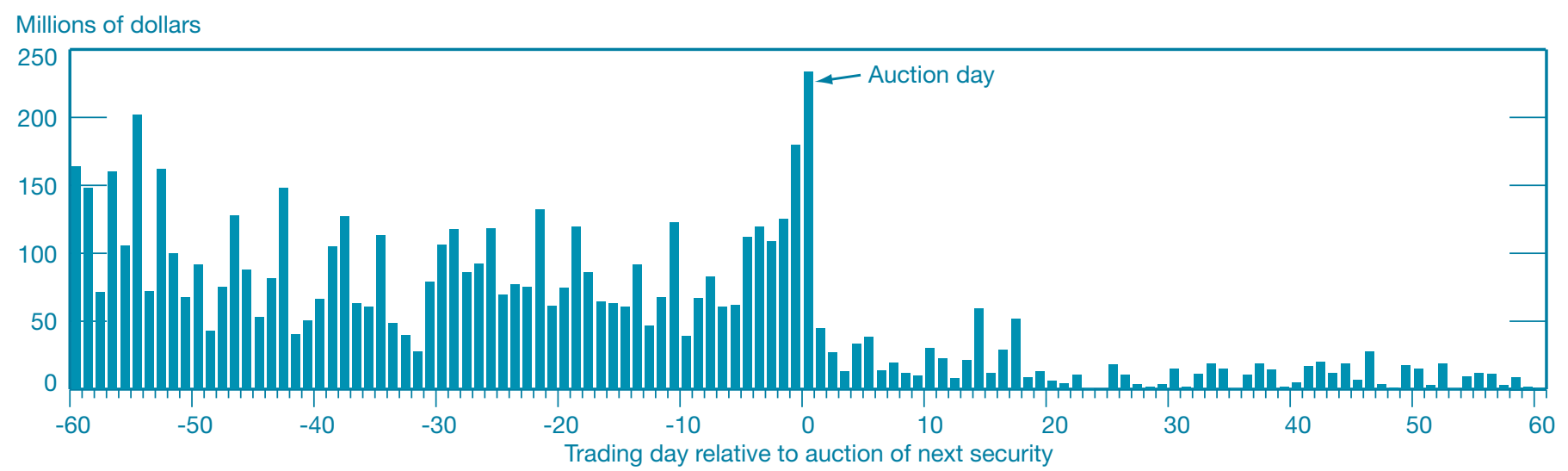

Chart $1 \mathrm{~B}$

Trading Frequency around Off-the-Run Date

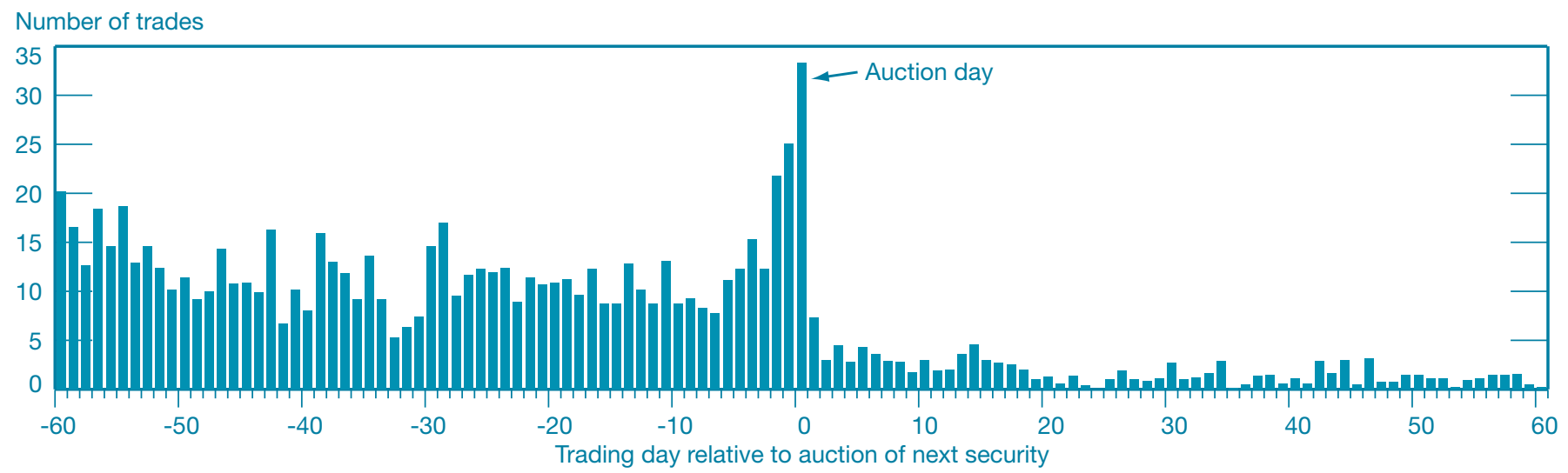

Source: Authors' calculations, based on proprietary data from the interdealer market.

Note: The charts plot average trading activity of ten TIPS (two five-year notes, five ten-year notes, and three twenty-year bonds) that went off the run during the sample period by trading day relative to the auction day of the next security within each security's sector.

a concentration of liquidity in just a few securities and also in those securities that tend to have the largest floating supplies. ${ }^{17}$

While there is a similar on-the-run/off-the-run divergence in daily trading frequency, such a pattern is not evident in trade size. In fact, average trade sizes are actually slightly higher for off-the-run TIPS. For the ten-year note, for example, average on-the-run trade size is $\$ 7.2$ million, whereas average off-therun trade size is $\$ 9.9$ million. Barclay, Hendershott, and Kotz (2006) uncover a similar pattern in the nominal market, whereas Goldreich, Hanke, and Nath (2005) report smaller trade sizes for off-the-run securities. One explanation for our

\footnotetext{
${ }^{17}$ On-the-run securities tend to have the largest floating supplies because Treasury securities tend to be increasingly owned by buy-and-hold investors as the time since issuance passes.
}

finding is that there is a compositional change in the type of trades executed when a security goes off the run, with a proportional reduction in frequent, small speculative trades, resulting in a higher trade size despite lower overall activity. ${ }^{18}$

The change in trading volume that occurs when a security goes off the run is quite abrupt in the TIPS market (Chart 1A). Trading volume averages $\$ 92$ million per day in the last sixty days before a security goes off the run and \$14 million in the first sixty days it is off the run. Moreover, average daily volume plunges from $\$ 234$ million on the last day a security is on the

${ }^{18}$ Barclay, Hendershott, and Kotz (2006) find that interdealer trading in the Treasury market migrates from electronic brokers to voice brokers when securities go off the run, which could be related to a compositional change in the type of trading. 
TABLE 4

Quote Measures by On-the-Run/Off-the-Run

Status and Sector

Panel A: On-the-Run Securities

\begin{tabular}{lccc} 
Sector & Bid-Ask Spread & Quote Size & Quote Incidence \\
\hline Five-year & 2.6 & 1.3 & 40.7 \\
Ten-year & 3.3 & 1.3 & 57.8 \\
Twenty-year & 7.3 & 1.1 & 26.7
\end{tabular}

Panel B: Off-the-Run Securities

\begin{tabular}{lccc} 
Sector & Bid-Ask Spread & Quote Size & Quote Incidence \\
\hline Five-year & 2.6 & 1.1 & 18.6 \\
Ten-year & 2.7 & 1.3 & 17.2 \\
Twenty-year & 7.3 & 1.1 & 7.3
\end{tabular}

Source: Authors' calculations, based on proprietary data from the interdealer market.

Notes: The table reports average daily quote statistics in TIPS over the March 4, 2005, to March 27, 2008, period. The quote incidence measure gauges the percentage of time (on trading days between 7:30 a.m. and 5 p.m.) that there is a two-sided quote in a security (that is, both a posted bid price and a posted offer price). Bid-ask spreads are in 32 nds of a point (a point equals 1 percent of par); quote sizes are in millions of dollars, par value.

run (that is, the auction day of the next security) to $\$ 45$ million the day after. The pattern is even more striking when examined in terms of trading frequency (Chart 1B). Similar patterns for nominal Treasury securities are reported by Fleming (2002), Goldreich, Hanke, and Nath (2005), and Barclay, Hendershott, and Kotz (2006).

Despite the sharp volume differential between on-the-run and off-the-run TIPS, there is virtually no difference in average bid-ask spreads or quoted depth between on-the-run and offthe-run securities (Table 4). Quoted bid-ask spreads average $2 \frac{1}{2}$ to $3 \frac{1}{2} 232$ nds of a point for on-the-run and off-the-run fiveand ten-year notes (a point equals 1 percent of par), and about 732 nds for twenty-year bonds. The average quantity available at the inside bid and offer prices is only somewhat higher than the minimum quote size of $\$ 1$ million for on-the-run and offthe-run TIPS in all sectors. Such results differ markedly from those in the nominal market, where studies find a sharp widening of bid-ask spreads and a decrease in quoted depth when securities go off the run (Fleming 2002; Goldreich, Hanke, and Nath 2005).

A notable aspect of average quote sizes is that they are dwarfed by average trade sizes. For example, the average quote size for the on-the-run ten-year note is $\$ 1.3$ million, but the average trade size for the note is $\$ 7.2$ million. The most important reason for the discrepancy is probably the "workup" process, whereby the initial buyer and seller as well as subsequent buyers and sellers can agree to trade additional amounts at the same price. Trade sizes reflect the total amounts

The results, taken together, highlight the limitations of the bid-ask spread and quoted depth as liquidity measures in the TIPS market.

traded in a single workup. Studies of the nominal market have found average trade sizes to exceed average quote sizes, but to a lesser degree and only for bills and off-the-run notes, not for on-the-run notes (Fleming 2002, 2003; Goldreich, Hanke, and Nath 2005).

An additional reason for the discrepancy between quote sizes and trade sizes is that the quote sizes reflect only shown amounts. Dealers can enter iceberg orders, however, whereby they commit to buying or selling a certain quantity at a certain price, with part of the quantity visible on the broker screen and the remainder hidden. Hidden amounts become visible to the market incrementally if and only if the initial shown amount is traded against. Recall that hidden depth accounts for only a small share of total depth in the nominal market.

While bid-ask spreads and quoted depth are similar for on-the-run and off-the-run securities, "quote incidence" is markedly higher for on-the-run securities. Quote incidence gauges the percentage of time in which there are two-sided quotes in a security (that is, both a posted bid price and a posted offer price). This proportion averages close to 60 percent for the on-the-run ten-year note (during New York trading hours, 7:30 a.m. to 5 p.m. Eastern time), but only about 15 percent for any given off-the-run ten-year note. That is, for off-the-run ten-year notes, there is a one-sided quote, or no quote, about 85 percent of the time.

The results, taken together, highlight the limitations of the bid-ask spread and quoted depth as liquidity measures in the TIPS market. Such spreads and depth are similar for on-therun and off-the-run securities, although they are available much less frequently for the latter. That is, measured liquidity among TIPS in a particular sector largely varies across the quote incidence dimension as opposed to the spread or quoted depth dimensions. In contrast, liquidity is found to vary across all of these dimensions in the nominal market. 


\subsection{Price Impact of Trades}

We assess the price impact of trades in the TIPS market by relating price changes to measures of net order flow, defined as purchases minus sales. (While every trade involves a purchase and sale, the buy or sell in such an analysis is defined by the side that initiates a trade.) Price impact is an important measure of liquidity because it gauges the extent to which prices move as a result of trading. The analysis is also useful for understanding the degree to which information relevant to TIPS prices is revealed through TIPS trading (versus through public information or trading in other markets).

Our particular analysis regresses daily price changes for the on-the-run securities of five-, ten-, and twenty-year maturities on net order flow in various sectors. ${ }^{19}$ As in Brandt and Kavajecz (2004), the use of daily data mitigates high-frequency microstructure effects and allows us to more cleanly estimate the more permanent price impact of trades. ${ }^{20}$ We estimate net order flow based on trading frequency, as in Fleming (2003), but describe robustness results with net order flow based on trading volume, as in Brandt and Kavajecz (2004).

Our results show the expected positive relationship between net order flow and price change: Nearly all coefficients are statistically significant at the 1 percent level (Table 5). Like Brandt and Kavajecz (2004), we find that order flow across the curve affects prices, so while the ten-year note price is affected most by order flow in securities with a remaining maturity of more than ten years, it is also affected by order flow in shorter-term securities. ${ }^{21}$ The adjusted $\mathrm{R}^{2}$ measures are close to 20 percent for all three price series, indicating that 20 percent of TIPS price variation can be explained by TIPS order flow alone.

We also estimate price impact by employing other model specifications. If net order flow is defined using trading volume instead of trading frequency, all of the coefficients are statistically significant at the 1 percent level, but the adjusted

\footnotetext{
${ }^{19}$ Price changes are calculated using closing (5 p.m.) prices from Bloomberg and net order flow is measured over the interval running from 6 p.m. one day to 5 p.m. the next day. Our analysis is limited to the 395 trading days in our sample for which we are not missing data for any on-the-run securities (although results are quite similar if we look at all 757 days in our sample). We are careful to never measure price changes across securities (so the first day a security is on the run, we estimate the daily price change from the previous day's price for that security and not from the price of the security that was on the run at the time).

${ }^{20}$ A higher-frequency analysis is also somewhat problematic because of the low frequency of TIPS trading. It is for this reason that we estimate price impact only for on-the-run securities and that we do not assess price impact when we examine announcement effects.

${ }^{21}$ For all three price series, the shorter-term order flow coefficients are insignificantly different from one another at the 10 percent level, but significantly different from the long-term order flow coefficient at the 1 percent level. In the nominal market, in contrast, Brandt and Kavajecz (2004) find order flow in the two- to five-year sector as being particularly important in explaining yield changes across the curve.
}

TABle 5

Price Impact of Trades

\begin{tabular}{lccc} 
Independent & \multicolumn{3}{c}{ Dependent Variable: Price Change } \\
\cline { 2 - 4 } $\begin{array}{l}\text { Variable: } \\
\text { Net Order Flow }\end{array}$ & Five-Year & Ten-Year & Twenty-Year \\
\hline Constant & $0.65^{*}$ & $1.39^{* *}$ & $1.93^{* *}$ \\
& $(0.36)$ & $(0.60)$ & $(0.89)$ \\
Zero to five years & $0.18^{* * *}$ & $0.30^{* * *}$ & $0.34^{* * *}$ \\
& $(0.04)$ & $(0.07)$ & $(0.11)$ \\
Five to ten years & 0.10 & $0.26^{* * *}$ & $0.51^{* * *}$ \\
& $(0.06)$ & $(0.10)$ & $(0.15)$ \\
More than ten years & $0.47^{* * *}$ & $0.87^{* * *}$ & $1.45^{* * *}$ \\
& $(0.07)$ & $(0.12)$ & $(0.20)$ \\
\hline
\end{tabular}

Memo:

$\begin{array}{lccc}\begin{array}{c}\text { Adjusted } \mathrm{R}^{2} \\ \text { (percent) }\end{array} & 18.1 & 20.9 & 19.7 \\ \begin{array}{c}\text { Number of } \\ \text { observations }\end{array} & 395 & 395 & 395\end{array}$

Source: Authors' calculations, based on proprietary data from the interdealer market.

Notes: The table reports results from least squares regressions of daily price changes on net order flow over the March 4, 2005, to March 27, 2008, period. Price changes are measured for the on-the-run securities in 32nds of a point. Net order flow is measured as the daily net number of trades for all securities within a given time-to-maturity bucket. Coefficients are reported with heteroskedasticity- and autocorrelationconsistent (Newey-West) standard errors in parentheses.

\footnotetext{
${ }^{* * *}$ Statistically significant at the 1 percent level.

${ }^{*}$ Statistically significant at the 5 percent level.

${ }^{*}$ Statistically significant at the 10 percent level.
}

$\mathrm{R}^{2} \mathrm{~s}$ range only from 8 to 10 percent. If we add net volume to our model with the net number of trades, none of the volume coefficients is statistically significant at the 10 percent level either individually or as a group. Lastly, if we estimate the effects of buys and sells separately, we cannot reject the null hypothesis that the effects are equal in magnitude for order flow in a given sector for any of the price series.

\subsection{Intraday Patterns}

Intraday trading volume in TIPS is concentrated in the mid-tolate morning, roughly 9 a.m. to 11:30 a.m., and again in the afternoon right before 3 p.m. (Chart 2A). ${ }^{22}$ Trading frequency shows a similar pattern, whereas average trade size is more

${ }^{22}$ While the intraday patterns are presented only for the on-the-run ten-year note, results are qualitatively similar for other on-the-run securities. 
stable across the day (Charts $2 \mathrm{~B}$ and $2 \mathrm{C}$ ). The morning pattern for TIPS diverges from that for the nominal market, where activity peaks between 8:30 a.m. and 9 a.m. (see, for example, Fleming [1997] and Fleming and Mizrach [2009]). The morning peak in the nominal market is largely explained by the release of several important macroeconomic announcements at 8:30 a.m. (Fleming and Remolona 1999).

The later-morning peak in activity in the indexed market may reflect differences in use and ownership between nominal and inflation-indexed securities. In particular, TIPS activity is

Chart 2A

Intraday Trading Volume of On-the-Run Ten-Year Note

Millions of dollars

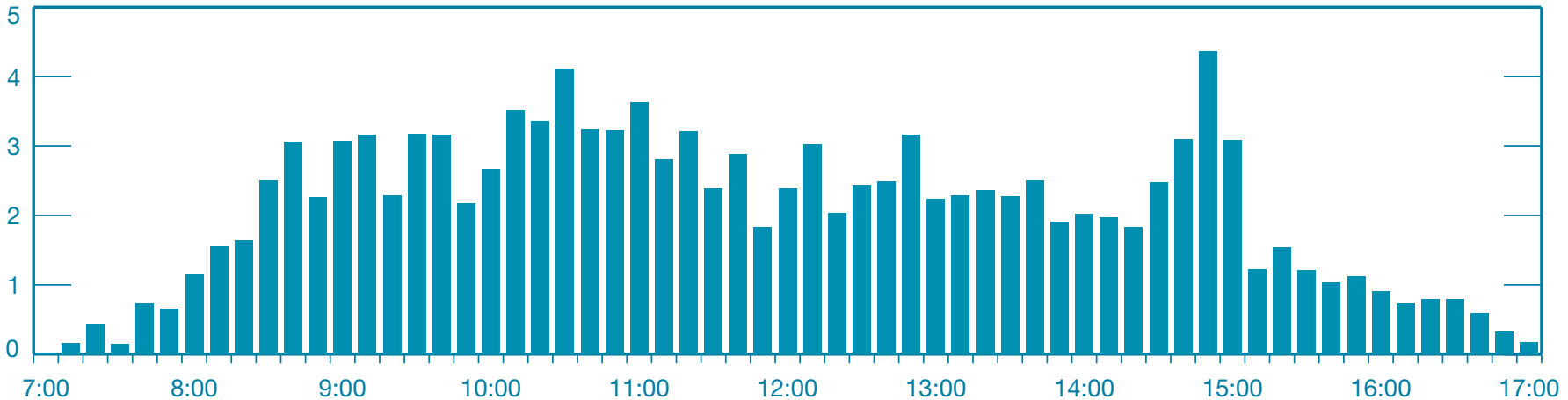

Chart 2B

Intraday Trading Frequency of On-the-Run Ten-Year Note

Number of trades

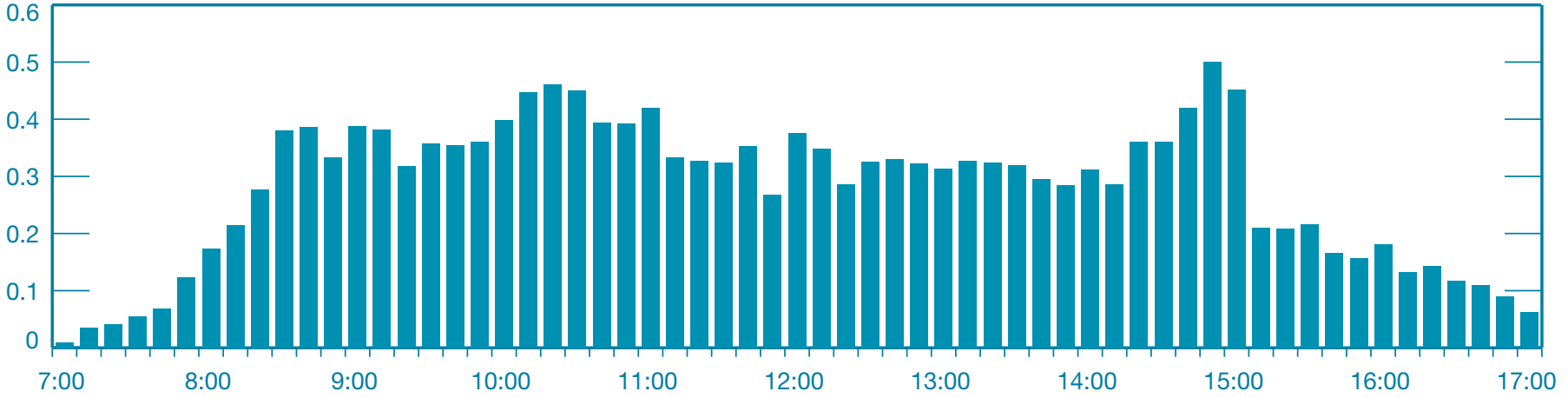

Chart 2C

Intraday Trade Size of On-the-Run Ten-Year Note

Millions of dollars

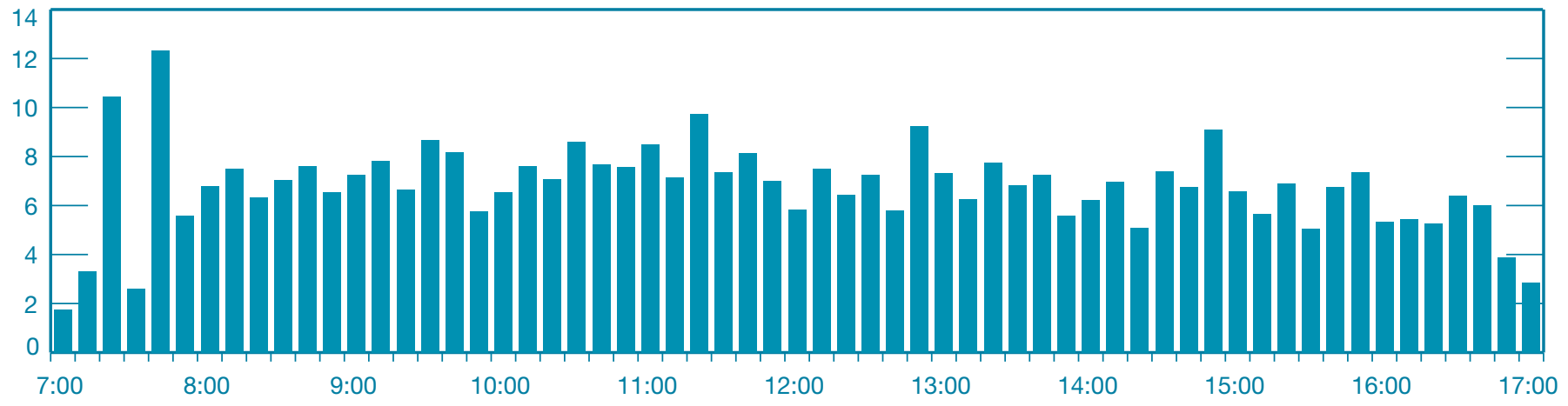


Chart 2D

Intraday Bid-Ask Spread of On-the-Run Ten-Year Note

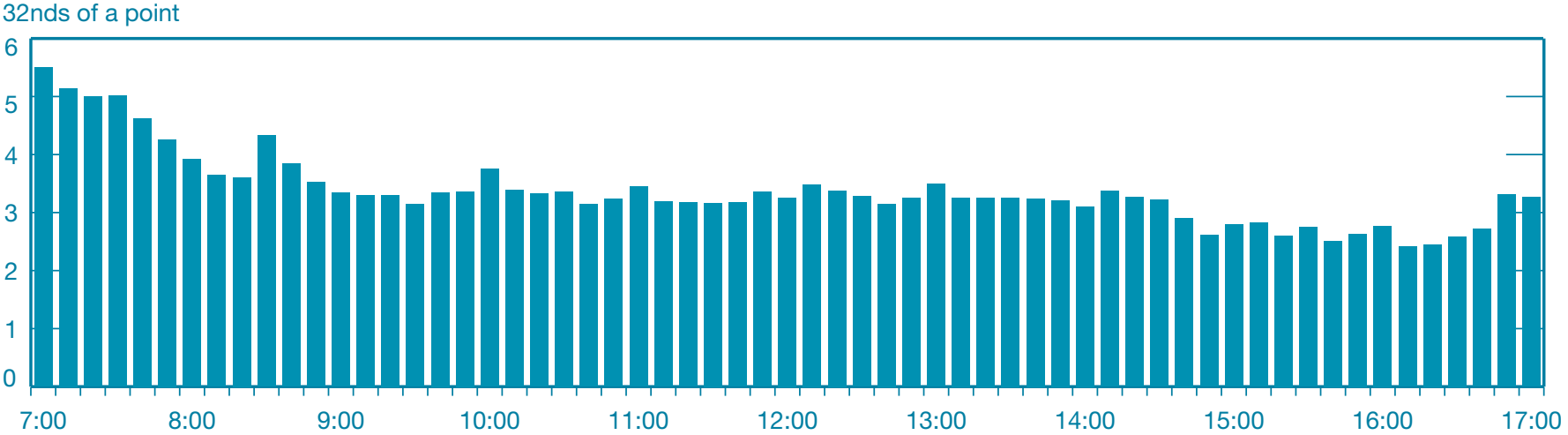

Chart 2E

Intraday Price Volatility of On-the-Run Ten-Year Note

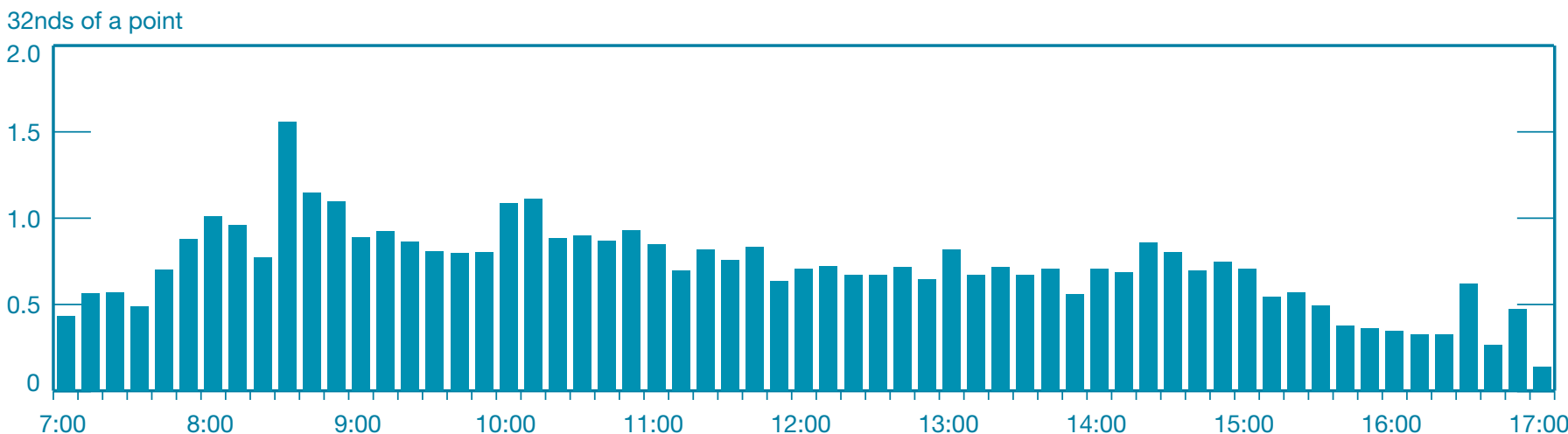

Chart $2 \mathrm{~F}$

Intraday Quote Incidence of On-the-Run Ten-Year Note

No quote

One-sided quote

Two-sided quote

\section{Percent of time}

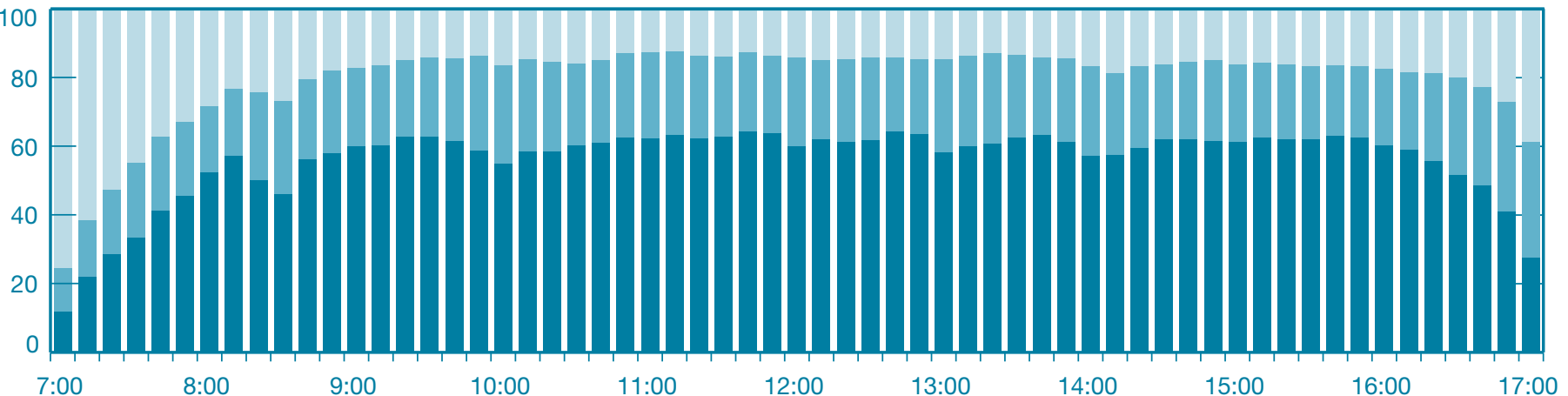

Source: Authors' calculations, based on proprietary data from the interdealer market.

Notes: The charts plot average levels of trading activity, liquidity, and price volatility for the on-the-run ten-year TIPS for each ten-minute interval over the trading day. The average bid-ask spread and trade size are first calculated for each ten-minute interval before averaging across days. Price volatility is calculated as the average absolute price change for each ten-minute interval. Times noted are interval start times. 
probably driven more by institutional trading demands that are best met when the market is less volatile and trading costs are lower (that is, after the 8:30 a.m. and occasional 9:15 a.m. and 10 a.m. announcements). In contrast, speculative and hedging considerations may dominate in the nominal market, causing activity to peak shortly after announcements, despite the high volatility and trading costs.

The peak before 3 p.m. also occurs in the nominal market but is more pronounced for TIPS, which perhaps again reflects differences in use and ownership between nominal and inflation-indexed securities. In particular, TIPS activity is probably driven more by institutional investors, who are more likely to be managing relative to a benchmark and who therefore want to trade as close to $3 \mathrm{p} . \mathrm{m}$. as possible to minimize tracking error (fixed-income indexes are priced at 3 p.m.). Consistent with this argument, we find that TIPS

\section{[Compared with activity in the nominal} market,] TIPS activity is probably driven more by institutional trading demands that are best met when the market is less volatile and trading costs are lower.

trading volume is particularly high on the last trading day of the month, when fixed-income indexes are rebalanced, and that the peak in trading before 3 p.m. is especially high on that day.

One other difference in intraday activity between TIPS and nominal securities is that there is virtually no overnight trading of TIPS: Less than 0.1 percent of TIPS trading volume occurs outside of New York trading hours. In contrast, analyses of the nominal market find that about 5 percent of interdealer trading occurs outside New York hours (Fleming 1997; Fleming and Mizrach 2009). The dearth of overnight trading is consistent with the hypothesis that TIPS trading is driven more by lowerfrequency institutional trading demands as opposed to higherfrequency hedging and speculative demands. It is consistent also with the evidence that foreign investors purchase TIPS to a lesser degree than they do nominal securities.

Bid-ask spreads for TIPS are at their widest at the beginning of the trading day, when trading is sparse (Chart 2D). Thereafter, they narrow sharply as trading volume picks up and then widen again at the end of the day as trading tapers off. Increases in the spread at 8:30 a.m. and 10 a.m. correspond to increases in price volatility (Chart $2 \mathrm{E}$ ), which are likely explained by the release of macroeconomic announcements at those times. The pattern of bid-ask spreads is similar to that observed for nominal Treasury securities (Fleming and
Remolona 1999). The volatility pattern is also similar to that in the nominal market (Fleming 1997; Fleming and Remolona 1999), albeit with less pronounced spikes at 8:30 a.m. and 10 a.m.

The intraday pattern of quote incidence for TIPS is also consistent with what one might expect given the pattern of trading activity (Chart $2 \mathrm{~F}$ ). That is, a two-sided quote is least likely to be posted at the beginning and end of the trading day, when trading activity is light.

\subsection{Announcement Effects at a Daily Level}

We first analyze the effects of announcements on trading activity at a daily level. At a daily frequency, announcement effects are easiest to discern for trading activity, as opposed to price volatility or bid-ask spreads, because such announcements have larger, more persistent effects on trading activity (Fleming and Remolona 1999; Balduzzi, Elton, and Green 2001).

The announcements we consider are the CPI release and the employment report (both produced by the Bureau of Labor Statistics), the Federal Open Market Committee (FOMC) post-meeting announcement, and TIPS auction results. The employment report is widely found to be the most important scheduled macroeconomic announcement in the nominal market (Ederington and Lee 1993; Fleming and Remolona 1997; Bollerslev, Cai, and Song 2000; Balduzzi, Elton, and Green 2001; Huang, Cai, and Wang 2002). FOMC announcements are also quite important (Kuttner 2001; Gürkaynak, Sack, and Swanson 2005; Fleming and Piazzesi 2005). CPI releases are also influential, but may be particularly so for TIPS given that cash flows on TIPS are tied to them. Auction results are often not included in announcement studies, but have been found to be associated with some of the sharpest price moves in the TIPS market (Dupont and Sack 1999).

We analyze announcement effects on trading activity by regressing daily trading volume and daily trading frequency on dummy variables for our various announcements. ${ }^{23}$ The results show that TIPS trading activity is nearly twice as high on TIPS auction days as on other days and also significantly higher on CPI and, to a lesser extent, FOMC announcement days (Charts $3 \mathrm{~A}$ and 3B). On TIPS auction days, trading volume averages $\$ 975$ million, versus $\$ 527$ million on nonannouncement days (days without a TIPS auction or a CPI

${ }^{23}$ We consider all CPI and employment report announcements in our sample, all TIPS auctions (for new securities or reopenings of existing securities), and FOMC announcements after scheduled meetings (but not unscheduled meetings). 
Chart 3A

Trading Volume on Announcement

and Nonannouncement Days

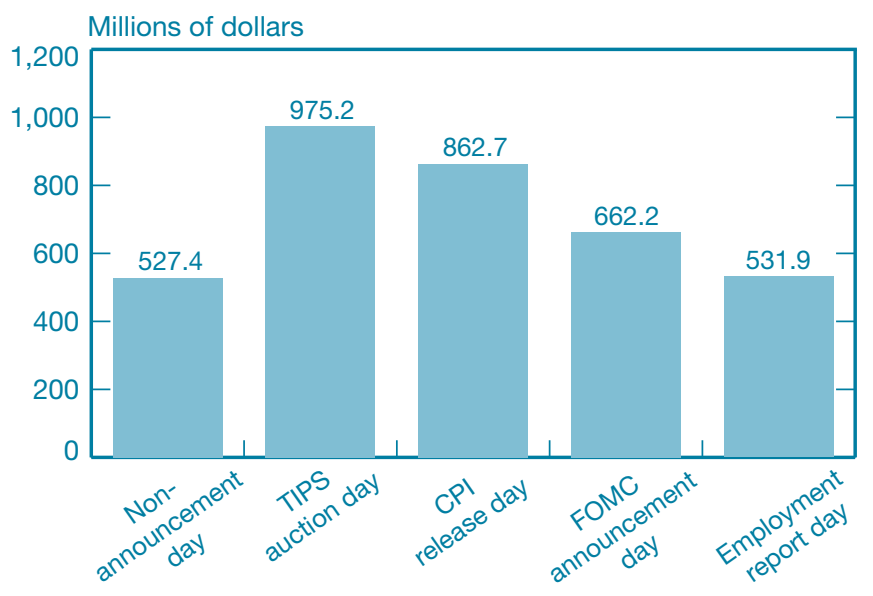

Chart $3 \mathrm{~B}$

Trading Frequency on Announcement and Nonannouncement Days

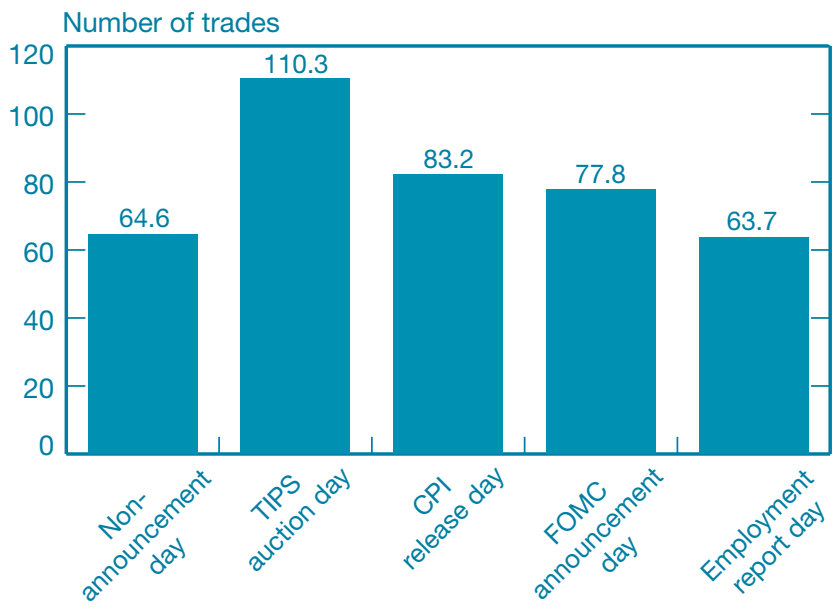

Source: Authors' calculations, based on proprietary data from the interdealer market.

Notes: The charts plot the coefficients from regressions of daily trading activity in TIPS on dummy variables for TIPS auction days, CPI release days, FOMC announcement days, employment report days, and nonannouncement days (days without any of the aforementioned announcements). By construction, such coefficients equal the average level of trading activity in TIPS on the various announcement days (controlling for other announcements) and nonannouncement days.

release, employment report, or FOMC announcement). On $\mathrm{CPI}$ and FOMC announcement days, trading volume averages $\$ 863$ million and \$662 million, respectively. On employment report announcement days, in contrast, volume is insignificantly different from volume on nonannouncement days. The announcement effects are similar when controlling for the day of the week. ${ }^{24}$

These announcement effects are somewhat different from those found in the nominal market. Recall that the employment report is widely found to be highly important in the nominal market and to spur significant increases in trading activity (Fleming and Remolona 1997; Balduzzi, Elton, and Green 2001), but it appears to have little effect on TIPS activity at the daily level. The CPI announcement is also found to elicit increases in activity in the nominal market, and large effects for TIPS in particular are not surprising. The modest increases in activity on FOMC days are also consistent with evidence for the nominal market (Fleming and Piazzesi 2005). The auction results are the most striking, and they are consistent with the limited evidence available from the nominal market. ${ }^{25}$

\subsection{High-Frequency Analysis of Announcement Effects}

A high-frequency analysis allows us to discern the effects of announcements more precisely and thus better ascertain how the market adjusts to announcements. The particular variables we consider, which are commonly examined in announcement studies in the nominal market, are price volatility, trading frequency, and bid-ask spread. As in nominal market studies, we conduct the analysis by comparing the intraday behavior of these variables on announcement days with the behavior on nonannouncement days. Such an analysis allows for a clean examination of announcement effects, controlling for the typical intraday pattern, because announcements of a given type are released at essentially the same time on announcement days. CPI and employment report announcements are released at 8:30 a.m., auction results within a few minutes of the 1 p.m. auction close, and FOMC post-meeting announcements at around 2:15 p.m.

Our findings across announcements are generally consistent with those of other studies of the nominal market. According to those studies, price volatility spikes at the time of a major

${ }^{24}$ There are pronounced day-of-week effects in trading activity in the TIPS market, as there are in the nominal market. In particular, trading volume is lowest on Monday, averaging $\$ 424$ million. It is highest on Wednesday and Thursday, averaging $\$ 615$ million and $\$ 658$ million, respectively. On Tuesday and Friday, volume is somewhere in between, at \$552 million and \$546 million, respectively. These patterns remain when controlling for the announcements examined here.

${ }^{25}$ The effects of auction announcements on the nominal market have not been examined in detail, but Fleming and Remolona (1997) and Huang, Cai, and Wang (2002) do find an immediate increase in trading activity after announcements of auction results. A related literature examines market behavior around auctions (for example, Nyborg and Sundaresan [1996]), but it is not generally concerned with the effects of auctions on outstanding securities. 
Chart 4A

Intraday Price Volatility on CPI and Nonannouncement Days

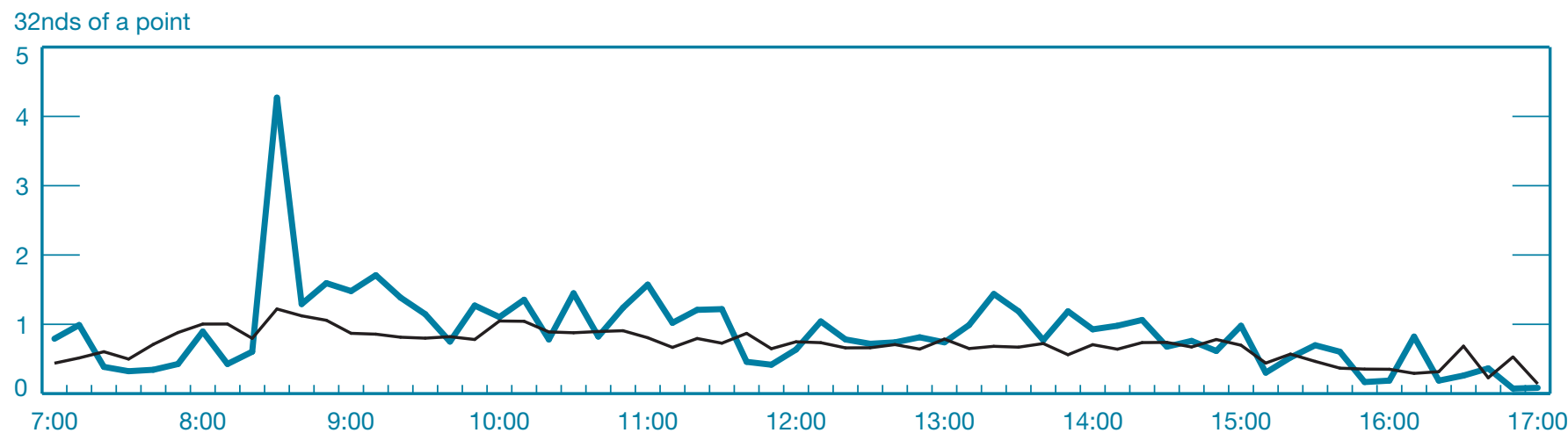

Chart 4B

Intraday Trading Frequency on CPI and Nonannouncement Days

Number of trades

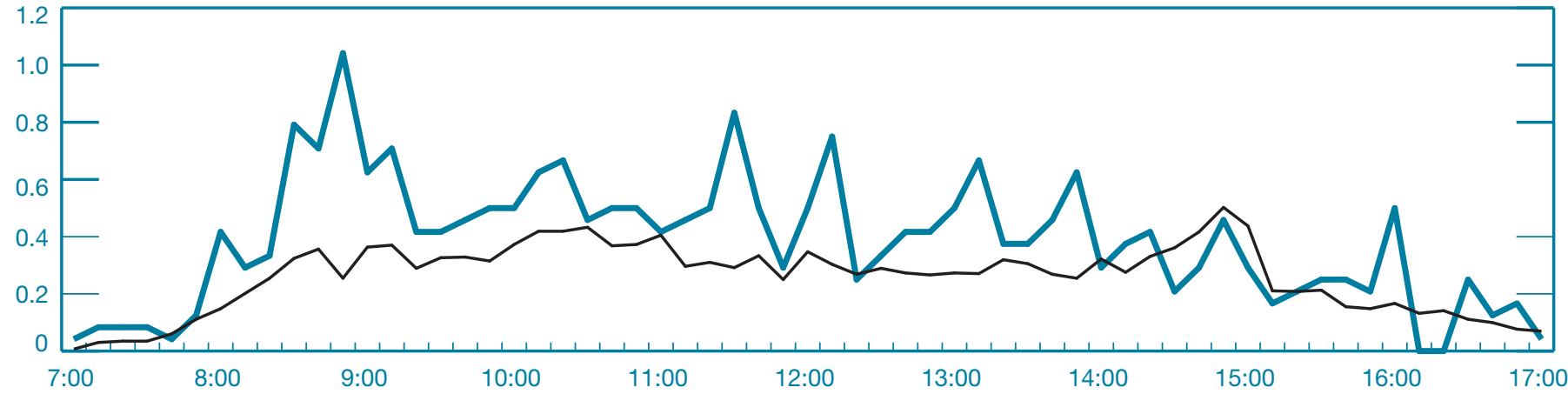

Chart 4 C

Intraday Bid-Ask Spread on CPI and Nonannouncement Days

32nds of a point

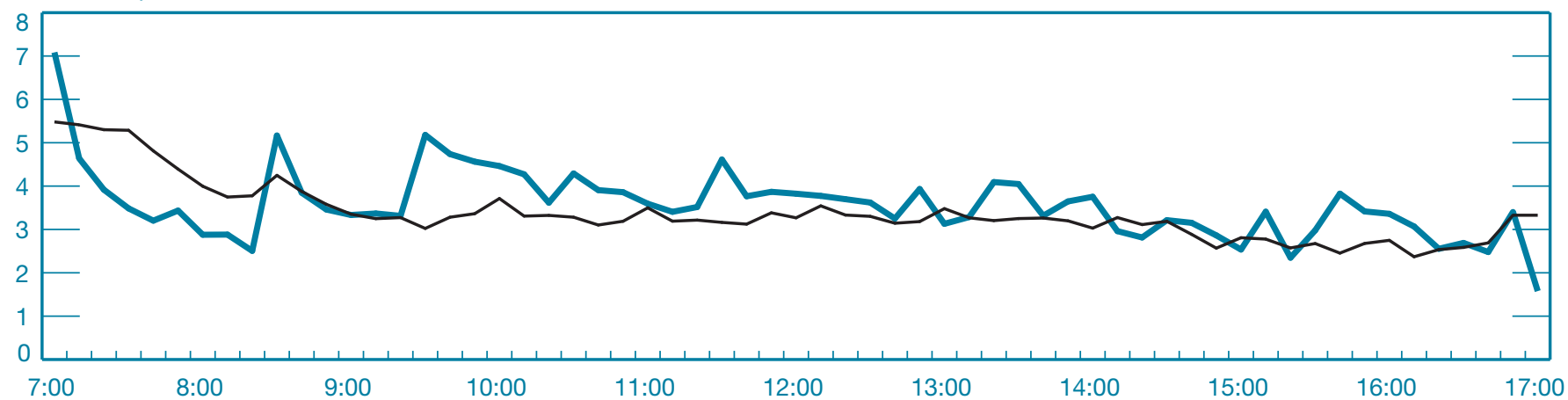

Source: Authors' calculations, based on proprietary data from the interdealer market.

Notes: The charts plot intraday patterns of price volatility, trading frequency, and bid-ask spreads for the on-the-run ten-year TIPS on CPI announcement days (in blue) and nonannouncement days (in black). Times noted are interval start times. 
Chart 5A

Intraday Price Volatility on Employment Report and Nonannouncement Days

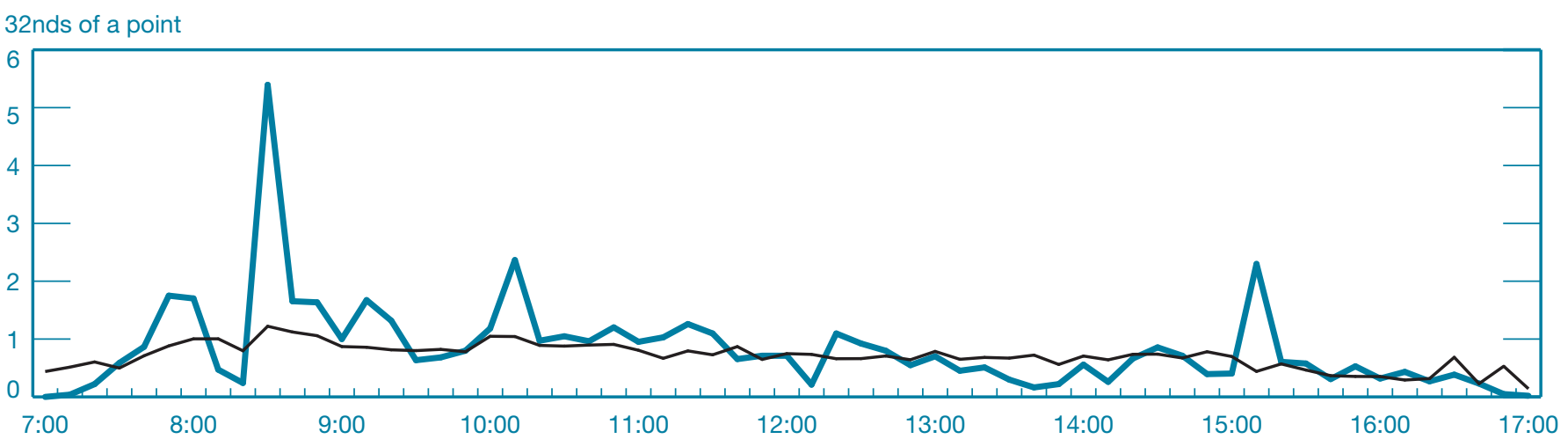

Chart 5B

Intraday Trading Frequency on Employment Report and Nonannouncement Days

\section{Number of trades}

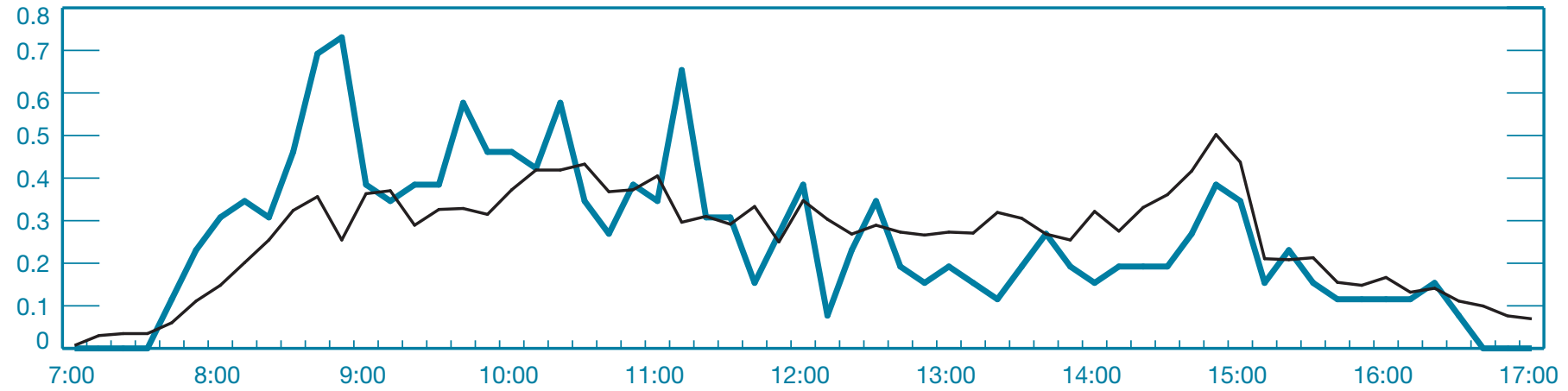

Chart 5C

Intraday Bid-Ask Spread on Employment Report and Nonannouncement Days

32nds of a point

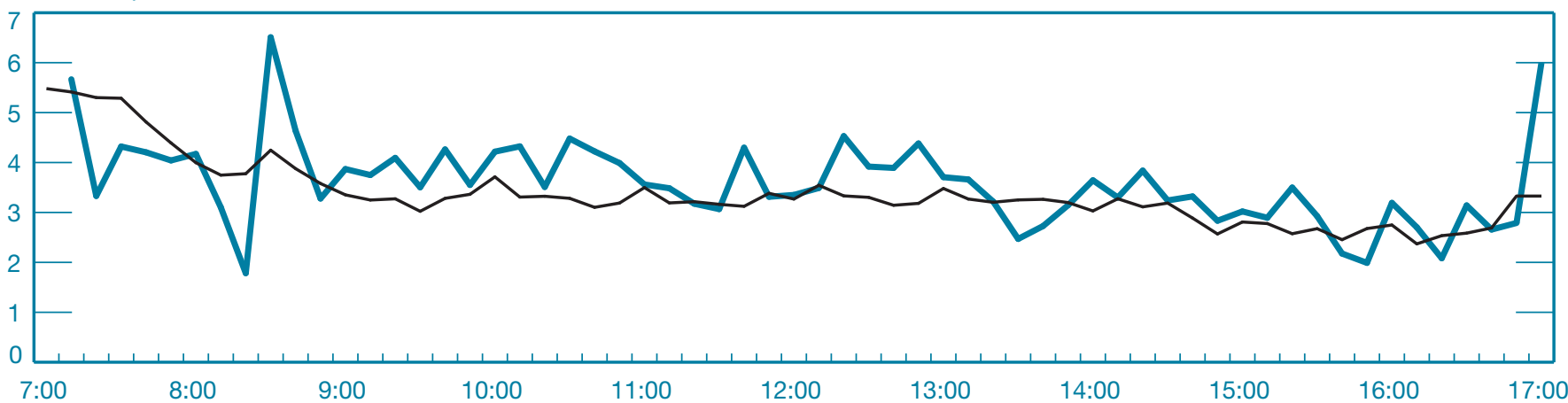

Source: Authors' calculations, based on proprietary data from the interdealer market.

Notes: The charts plot intraday patterns of price volatility, trading frequency, and bid-ask spreads for the on-the-run ten-year TIPS on employment report days (in blue) and nonannouncement days (in black). Times noted are interval start times. 
Chart 6A

Intraday Price Volatility on FOMC and Nonannouncement Days

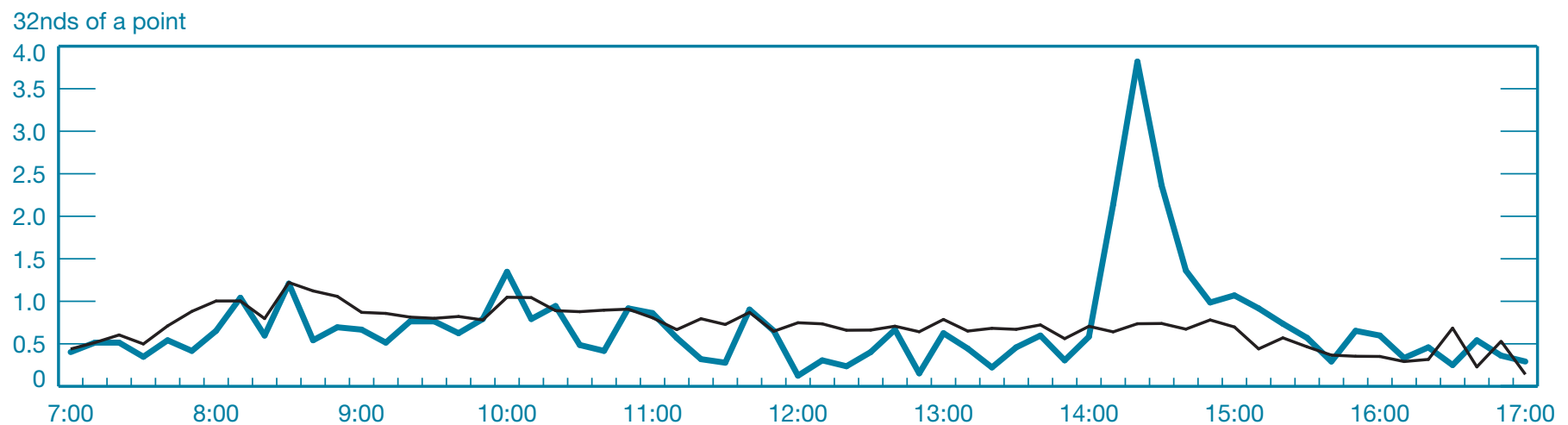

Chart 6B

Intraday Trading Frequency on FOMC and Nonannouncement Days

Number of trades

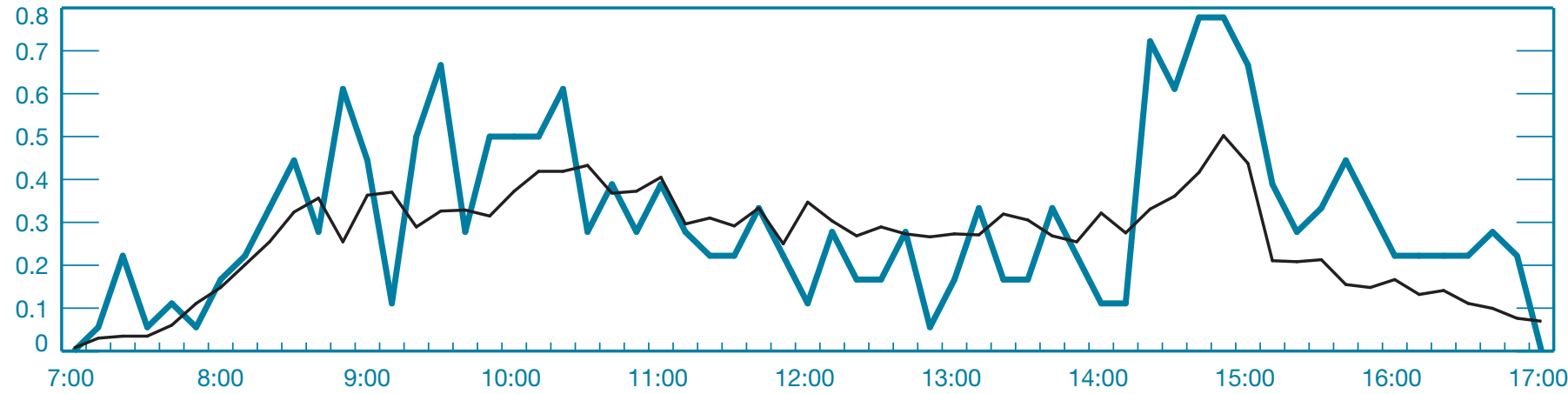

Chart 6C

Intraday Bid-Ask Spread on FOMC and Nonannouncement Days

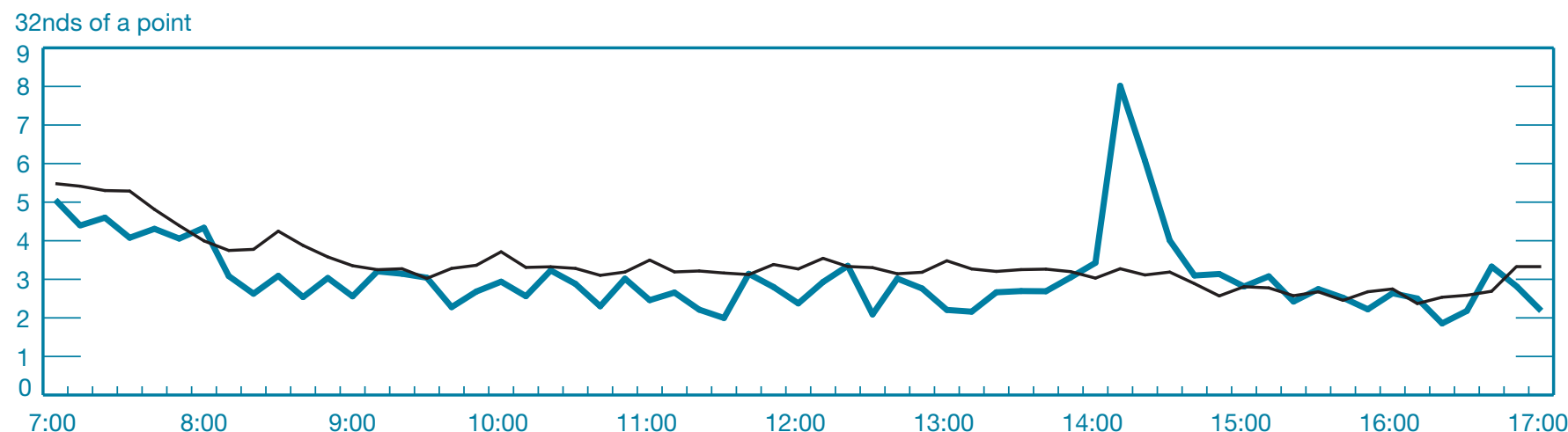

Source: Authors' calculations, based on proprietary data from the interdealer market.

Notes: The charts plot intraday patterns of price volatility, trading frequency, and bid-ask spreads for the on-the-run ten-year TIPS on FOMC announcement days (in blue) and nonannouncement days (in black). Times noted are interval start times. 
Chart 7A

Intraday Price Volatility on Auction and Nonannouncement Days

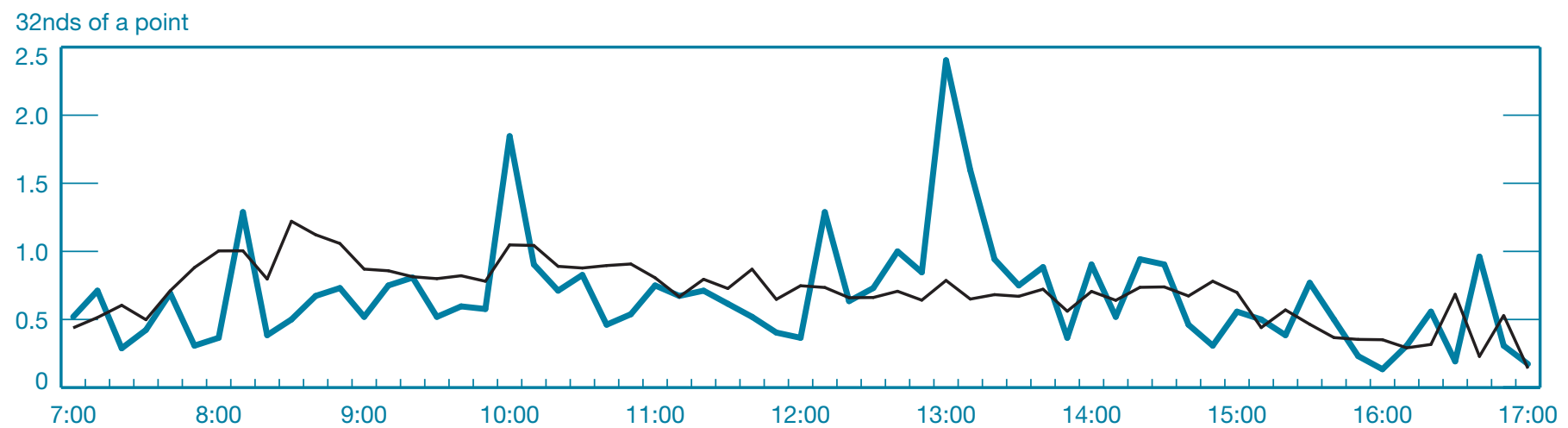

Снart 7 B

Intraday Trading Frequency on Auction and Nonannouncement Days

Number of trades

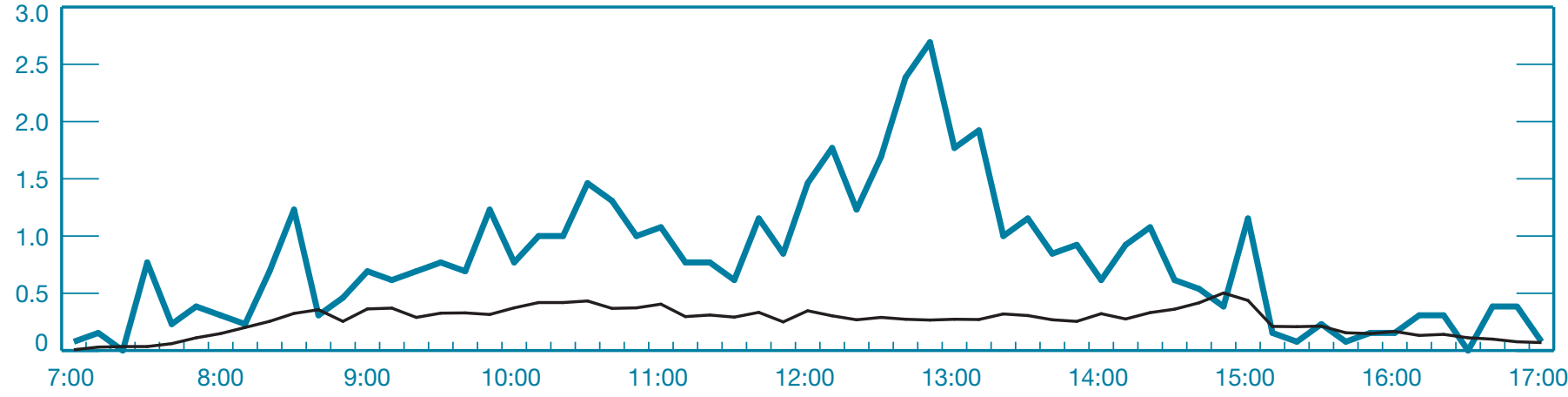

Chart 7C

Intraday Bid-Ask Spread on Auction and Nonannouncement Days

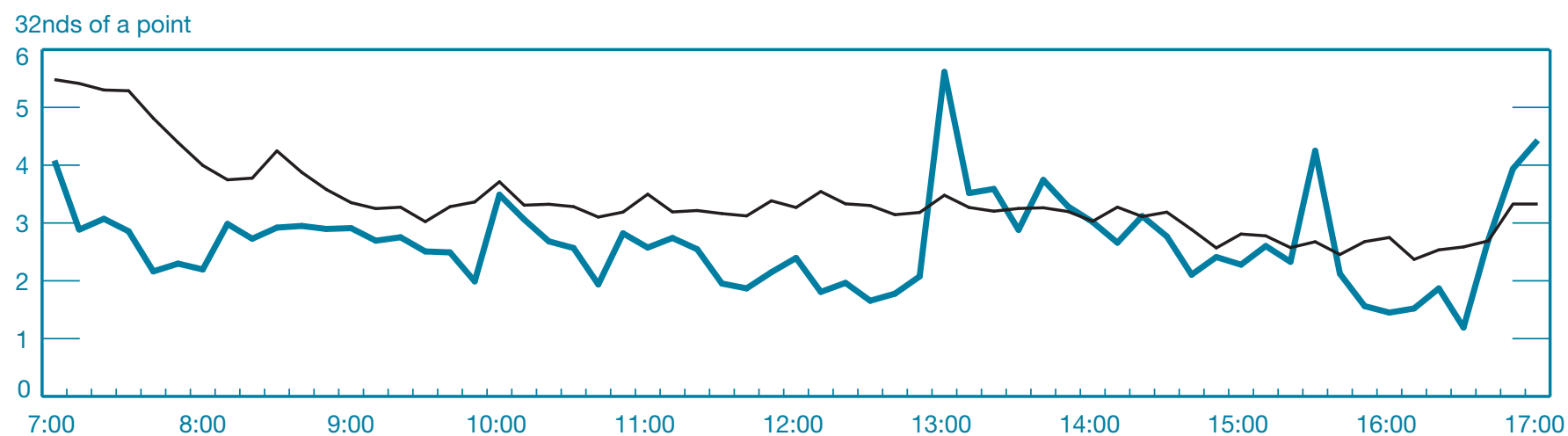

Source: Authors' calculations, based on proprietary data from the interdealer market.

Notes: The charts plot intraday patterns of price volatility, trading frequency, and bid-ask spreads for the on-the-run ten-year TIPS on TIPS auction days (in blue) and nonannouncement days (in black). Times noted are interval start times. 
announcement and then remains somewhat higher than usual for some time (see, for example, Fleming and Remolona 1999]; Balduzzi, Elton, and Green [2001]; and Fleming and Piazzesi [2005]). Our price volatility findings are consistent with this result for every announcement (Charts 4A-7A).

The increases in trading activity that occur at the time of announcement are also generally consistent with findings for the nominal market, whereby trading activity jumps right after the announcement and then remains higher than usual for some time (Charts 4B-7B). The announcement that stands out in terms of trading activity is the one for TIPS auction results. In particular, trading activity on TIPS auction days is much higher than usual in the hours preceding the 1 p.m. auction close and then peaks in the ten-minute interval right before the close. While trading activity for other announcements seems to be driven by the news in the announcement, trading activity on TIPS auction days seems to be driven by positioning in advance of the auction.

Lastly, the pattern for bid-ask spreads is also consistent with findings for the nominal market, whereby spreads widen sharply at the time of the announcement but revert quickly to normal levels (Charts 4C-7C). The pattern for TIPS auction results fits this general pattern, but also indicates narrowerthan-usual spreads in the hours preceding the auction close, consistent with the higher-than-usual trading activity in that time period.

Our results also offer an interesting contrast with other findings from the TIPS market. While no other study analyzes the announcement adjustment process of TIPS, Beechey and Wright (2009) examine how TIPS yields are affected by surprises associated with the CPI, FOMC, employment report, and other announcements. Consistent with the spikes in volatility we find at the times of announcements, the authors find monetary policy surprises and employment report surprises to have significant effects on TIPS yields. However, they do not find core CPI surprises to be significantly related to yields, even though we do detect significant announcement effects from the CPI in terms of volatility, yields, and bid-ask spreads. Further work is needed to resolve these contrasting results. $^{26}$

\section{Conclusion}

Our analysis of the TIPS market identifies several microstructure features also present in the nominal Treasury securities market, but several unique features as well. As in the nominal market, there is a marked difference in trading activity between on-the-run and off-the-run TIPS, as trading drops sharply when securities go off the run. In contrast to the nominal market, there is little difference in bid-ask spreads or quoted depth between these securities, but there is a difference in the incidence of posted quotes. The results suggest that trading activity and quote incidence may be better crosssectional measures of liquidity in the TIPS market than bid-ask spreads or quoted depth.

Intraday patterns of trading activity are broadly similar in the TIPS and nominal markets, but TIPS activity peaks somewhat later, likely indicating differences in the use and ownership of these securities. Announcement effects are also different, probably reflecting the types of information most important to the particular securities. The employment report is the most important announcement in the nominal market, but it elicits relatively little response in the TIPS market in terms of trading activity. In contrast, announcements of the consumer price index and the results of TIPS auctions precipitate significant increases in TIPS trading activity, likely indicating these announcements' particular importance to TIPS valuation.
${ }^{26}$ The contrasting results are probably not explained by differences in sample periods, which are largely similar between the two studies, or by differences in event interval, which also are similar. The differences may be explained by differential effects between core CPI and overall CPI surprises or by TIPS yields not reacting in a consistent, linear manner to core CPI surprises. 


\section{REFERENCES}

Balduzzi, P., E. J. Elton, and T. C. Green. 2001. "Economic News and Bond Prices: Evidence from the U.S. Treasury Market.” JournaL of Financial and Quantitative Analysis 36, no. 4 (December): 523-43.

Barclay, M., T. Hendershott, and K. Kotz. 2006. "Automation versus Intermediation: Evidence from Treasuries Going Off the Run.” Journal of Finance 61, no. 5 (October): 2395-414.

Beechey, M. J., and J. H. Wright. 2009. "The High-Frequency Impact of News on Long-Term Yields and Forward Rates: Is It Real?" Journal of Monetary Economics 56, no. 4 (May): 535-44.

Bollerslev, T., J. Cai, and F. M. Song. 2000. "Intraday Periodicity, Long Memory Volatility, and Macroeconomic Announcement Effects in the U.S. Treasury Bond Market." Journal of EMPIRICAL Finance 7, no. 1 (May): 37-55.

Boni, L., and C. Leach. 2004. "Expandable Limit Order Markets." Journal of Financial Markets 7, no. 2 (February): 145-85.

Brandt, M. W., and K. A. Kavajecz. 2004. "Price Discovery in the U.S. Treasury Market: The Impact of Order Flow and Liquidity on the Yield Curve." Journal of Finance 59, no. 6 (December): 2623-54.

Buraschi, A., and A. Jiltsov. 2005. "Inflation Risk Premia and the Expectations Hypothesis.” Journal of Financial Economics 75, no. 2 (February): 429-90.

Campbell, J. Y., and R. J. Shiller. 1997. "A Scorecard for Indexed Government Debt.” In Ben Bernanke and Julio Rotermberg, eds., NBER Macroeconomics Annual, 155-97. Cambridge: MIT Press.

D’Amico, S., D. H. Kim, and M. Wei. 2008. “Tips from TIPS: The Informational Content of Treasury Inflation-Protected Security Prices." Board of Governors of the Federal Reserve System, Finance and Economics Discussion Series, no. 2008-30, June.

Dudley, W. C., J. Roush, and M. S. Ezer. 2009. “The Case for TIPS: An Examination of the Costs and Benefits.” Federal Reserve Bank of New York Economic Policy Review 15, no. 1 (July): 1-17.

Dupont, D., and B. Sack. 1999. "The Treasury Securities Market: Overview and Recent Developments.” Federal Reserve Bulletin 85, no. 12 (December): 785-806.
Ederington, L. H., and J. H. Lee. 1993. "How Markets Process Information: News Releases and Volatility." JournaL of Finance 48, no. 4 (September): 1161-91.

Fabozzi, F. J., and M. J. Fleming. 2005. "U.S. Treasury and Agency Securities.” In Frank J. Fabozzi, ed., The Handbook of FixedIncome Securities, 7th ed. New York: McGraw-Hill.

Fleckenstein, M., F. A. Longstaff, and H. Lustig. 2010. "Why Does the Treasury Issue TIPS? The TIPS-Treasury Bond Puzzle.” NBER Working Paper no. 16358, September.

Fleming, M. J. 1997. “The Round-the-Clock Market for U.S. Treasury Securities.” Federal Reserve Bank of New York Economic Policy Review 3, no. 2 (July): 9-32.

2002. "Are Larger Issues More Liquid? Evidence from Bill Reopenings.” Journal of Money, Credit, and Banking 34, no. 3, part 2 (August): 707-35.

2003. "Measuring Treasury Market Liquidity.” Federal Reserve Bank of New York Economic Policy Review 9, no. 3 (September): 83-108.

2007. "Who Buys U.S. Treasury Securities at Auction?" Federal Reserve Bank of New York Current Issues in Economics And Finance 13, no. 1 (January).

Fleming, M. J., and B. Mizrach. 2009. "The Microstructure of a U.S. Treasury ECN: The BrokerTec Platform.” Federal Reserve Bank of New York Staff Reports, no. 381, July.

Fleming, M. J., and M. Piazzesi. 2005. "Monetary Policy Tick-by-Tick." Unpublished paper, August.

Fleming, M. J., and E. M. Remolona. 1997. "What Moves the Bond Market?" Federal Reserve Bank of New York Economic Policy Review 3, no. 4 (December): 31-50.

1999. "Price Formation and Liquidity in the U.S. Treasury Market: The Response to Public Information.” Journal of FinANCE 54, no. 5 (October): 1901-15.

Goldreich, D., B. Hanke, and P. Nath. 2005. "The Price of Future Liquidity: Time-Varying Liquidity in the U.S. Treasury Market." Review of Finance 9, no. 1 (January): 1-32. 


\section{References (Continued)}

Gürkaynak, R. S., B. Sack, and E. T. Swanson. 2005. "Do Actions Speak Louder than Words? The Response of Asset Prices to Monetary Policy Actions and Statements.” International Journal of Central Banking 1, no. 1 (May): 55-93.

Huang, R. D., J. Cai, and X. Wang. 2002. "Information-Based Trading in the Treasury Note Interdealer Broker Market." JournAL of Financial Intermediation 11, no. 3 (July): 269-96.

Kuttner, K. 2001. "Monetary Policy Surprises and Interest Rates: Evidence from the Fed Funds Futures Market.” JournaL of Monetary Economics 47, no. 3 (June): 523-44.

Nyborg, K. G., and S. Sundaresan. 1996. "Discriminatory versus Uniform Treasury Auctions: Evidence from When-Issued Transactions." Journal of Financial Economics 42, no. 1 (September): 63-104.
Pflueger, C. E., and L. M. Viceira. 2011. "An Empirical Decomposition of Risk and Liquidity in Nominal and Inflation-Indexed Government Bonds.” Unpublished paper, Harvard University.

Roush, J. E. 2008. “The 'Growing Pains' of TIPS Issuance.” Board of Governors of the Federal Reserve System, FinANCE AND Economics Discussion Series, no. 2008-08, February.

Sack, B., and R. Elsasser. 2004. "Treasury Inflation-Indexed Debt: A Review of the U.S. Experience." Federal Reserve Bank of New York Economic Policy Review 10, no. 1 (May): 47-63.

The views expressed are those of the authors and do not necessarily reflect the position of the Federal Reserve Bank of New York or the Federal Reserve System. The Federal Reserve Bank of New York provides no warranty, express or implied, as to the accuracy, timeliness, completeness, merchantability, or fitness for any particular purpose of any information contained in documents produced and provided by the Federal Reserve Bank of New York in any form or manner whatsoever. 